\title{
GC-MS analysis and antidiabetic potentials of Bridelia Micrantha crude extracts
}

\author{
Adewole Ezekiel $^{1,2 *}$, Sumera Zubai ${ }^{2}$, Ojo Abiodun ${ }^{1}$ and Jamshed Iqbal ${ }^{2}$ \\ ${ }^{1}$ Department of Chemical Sciences, Afe Babalola University Ado, Ekiti State, Nigeria \\ ${ }^{2}$ Department of Pharmacy, Centre for Advanced Drug Research (CADR), COMSATS Institute of information Technology, Abbottabad, Pakistan
}

\begin{abstract}
Background: The quest for continuous search for the use of plants for the cure of diabetes mellitus necessitated the research work.

Objective: The search for total and complete remedy for the treating of diabetes mellitus has necessitated the beaming of search light on bridelia micrantha for its potential anti-diabetic inhibitors.

Materials and method: The bark of the tree plant was obtained, air dried and turned to powdered. Extraction was done using methanol and chloroform solvents and

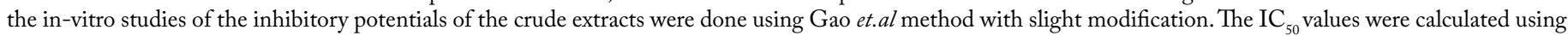
Graph pad prism 5.0software.

Results: Methanolic crude extract was found to be the most potent inhibitor of $\alpha$-glucosidase with $1.06 \pm 0.1 \mu \mathrm{g} / \mathrm{mL} \mathrm{IC} \mathrm{I}_{50}$ value and the chloroform crude extract had $2.84 \pm 0.1 \mu \mathrm{g} / \mathrm{mL} \mathrm{IC}_{50}$ which was better than standard inhibitor acarbose $\left.(234.6 \pm 2.01 \mu \mathrm{M})\right)$. The $\mathrm{IC}_{50}(7.35 \pm 1.0 \mu \mathrm{g} / \mathrm{mL})$ of chloroform extract showed less potent inhibitor against glucoamylase than that of methanolic extract with $\mathrm{IC}_{50}(1.12 \pm 0.10 \mu \mathrm{g} / \mathrm{mL})$. The $\beta$-glucosidase screening of the extracts showed that they do not potent and selective inhibitors. The high inhibitory effects of the extracts against glucoamylase and $\alpha$-glucosidase were confirmed by the presence of bioactive compounds present. The OSIRIS drug properties of some identified compounds was screened using online OSIRIS property explorer server and were found to possess various drug properties.
\end{abstract}

Conclusion: The in vitro assays of these extracts indicated that they are therapeutically interesting and could serve as important tools for treatment of diabetes.

\section{Introduction}

Diabetes mellitus disease has been a major ailment around the world and Nigeria not being exempted from the dreaded disease. The searching for the complete eradication of the disease through the use of plants has consistently been a major task for the pharmaceutical chemists. Diabetes mellitus is said to be a group of metabolic disorders manifested by innate or acquired failure to transport glucose from blood stream to cells [1]. There are many anti-diabetes inhibitors and among which are $\alpha$-glucosidase, $\beta$-glucosidase. $\alpha$-glucosidase inhibitors are oral drugs made for DM type 2 and it works by disallowing the digestion of carbohydrates and thereby reducing the impact of carbohydrate on blood sugar. Generally, plants are considered to be a source for the most active, potent hypoglycaemic properties [2,3]. Natural drugs from plants are considered to be nontoxic with lesser side effects than synthetic drugs. It has been reported that medicinal plants possessing anti-diabetic activities could be a useful tool for the discovery of safer hypoglycaemic agents [4]. These plants are said to be the major source for discovering new compounds with therapeutic value for drug development against most common and very prevalent disease, diabetes mellitus. The plants which have therapeutic application possess bioactive composites viz., alkaloids, glycosides, tannins, flavonoids, saponins, phenolics and vitamins [5]. B. micrantha is a medium sized semi-deciduous to deciduous tree that grows up to $20 \mathrm{~m}$ tall and belongs to the family Euphorbiaceae [6]. In Nigeria, different parts of the plant are used traditionally in the treatment of some ill-health by different cultural groups [7]. Pharmacological properties such as antidiabetic, antioxidant [6,8], anti-inflammatory [7], hepatoprotective [9] and abortifacient [10] activities of the plant have been reported. Bark of $B$. micrantha plant has been previously evaluated for its phytochemicals; Saponins Alkaloids Tannins Phytosterols Glycosides Flavonoids [11].

\section{Research Methodology}

\section{Research laboratory}

The research work was carried out at the centre for the Advanced Drug Research (CADR), Department of Pharmacy, COMSATS Institute of Information and Technology, Abbottabad, Pakistan in the month of July, 2017.

\section{Materials and instruments}

All the chemicals, solvents used are of analytical grade, $\alpha$-glucosidase (from Saccharomyces cerevisiae), substrate p-nitrophenyla-Dglucopyranoside (pNPG), $\beta$-glucosidase (from sweet almonds) and 96 well plates were purchased from Sigma Aldrich. ELIZA micro plate reader.

${ }^{\star}$ Correspondence to: Adewole Ezekiel, Department of Chemical Sciences, Afe Babalola University Ado, Ekiti State, Nigeria, E-mail: adewolen50@yahoo.com

Key words: anti-diabetes, ic50, bridelia micrantha, $\alpha$-glucosidase, $\beta$-glucosidases, gluco amylase, osiris drug properties, GC-MS

Received: August 11, 2018; Accepted: August 20, 2018; Published: August 27, 2018 


\section{Plant source}

B. micrantha belong to the family of Euphorbiaceae. The barks of the plant were obtained from a small farm in Akure South Local Government Area of Ondo State in Nigeria on the $5^{\text {th }}$ of April, 2017 and identified at the Department of crop and soil science, Federal University of Technology Akure, Nigeria.

\section{Plant preparation}

The barks were collected and air dried for one month and later grinded into powdered sample using grinder. The commercial grinder is made in China, brand MPN, having the following specifications; power $(2.2 \mathrm{kw})$, dimension $(34 \times 38 \times 75 \mathrm{~cm})$, roller length $(26 \mathrm{~cm})$, roller diameter $(14 \mathrm{~cm})$, voltage $(220 \mathrm{v} / 50 \mathrm{~Hz})$.

\section{Crude extract preparation}

Two hundred grams of powdered B. micrantha were soaked in $1000 \mathrm{ml}$ of Chloroform and methanol for five days and filtered through whatman filter paper. The extract was concentrated using a rotary evaporator at $35^{\circ} \mathrm{C}$ and the dried extract was stored at room temperature for further use. Ten milligram $(10 \mathrm{mg})$ of dried crude extracts were dissolved in $1 \mathrm{ml}$ of $100 \%$ Dimethyl sulfoxide (DMSO) and labelled as stock $(10 \mathrm{mg} / \mathrm{ml})$, working solution was made as $1 \mathrm{mg} / \mathrm{ml}$.

\section{$\alpha$-glucosidase inhibition study}

Assay for a-glucosidase inhibition was performed by slight modification of a previously published method [12]. Briefly, solutions of $\alpha$-glucosidase (from Saccharomyces cerevisiae) and its substrate p-nitrophenyl $\alpha$-D-glucopyranoside (pNPG) were prepared in phosphate buffer $(70 \mathrm{mM}, \mathrm{pH} 6.8)$. Buffer was used for the preparation of inhibitor solutions. The inhibition assays were conducted by adding inhibitor solution $(10 \mu \mathrm{L})$ to $70 \mu \mathrm{L}$ buffer and $10 \mu \mathrm{L}$ of enzyme solution $(2.5 \mathrm{unit} / \mathrm{mL})$ in $70 \mathrm{mM}$ phosphate buffer $(\mathrm{pH}$ 6.8) followed by pre-incubation at $37^{\circ} \mathrm{C}$ for $5 \mathrm{~min}$. After pre-incubation, $10 \mu \mathrm{L}$ of $10 \mathrm{mM}$ substrate (pNPG) prepared in phosphate buffer was added to the mixture to initiate enzymatic reaction. The reaction mixture was incubated at $37{ }^{\circ} \mathrm{C}$ for 30 minutes. Acarbose was used as a positive control. The $\alpha$-glucosidase activity was determined by measuring the p-nitrophenol released from pNPG at $405 \mathrm{~nm}$ using an Eliza micro plate reader. The experiment was performed in triplicates.

\section{$\beta$-glucosidase inhibition study}

The evaluation of inhibitory activity against $\beta$-glucosidase was performed with slight modification of the previously published method [13]. Briefly, $\beta$-glucosidase (from sweet almonds) enzyme and $p$-nitrophenyl $\beta$-D-glucopyranoside ( $\mathrm{pNPG)}$ as substrate were prepared in $0.07 \mathrm{M}$ phosphate buffer ( $\mathrm{pH}$ 6.8). The inhibition assays were conducted by adding inhibitor solution $(10 \mu \mathrm{L})$ to $70 \mu \mathrm{L}$ buffer and $10 \mu \mathrm{L}$ of enzyme solution $(2.0 \mathrm{unit} / \mathrm{mL})$ in $70 \mathrm{mM}$ phosphate buffer $(\mathrm{pH}$ 6.8) followed by pre-incubation at $37^{\circ} \mathrm{C}$ for $5 \mathrm{~min}$. After pre-read, $10 \mu \mathrm{L}$ of substrate was added to the mixture and then incubated at $37^{\circ} \mathrm{C}$ for $30 \mathrm{~min}$ and final reading was obtained. Negative control contained 10 $\mu \mathrm{L}$ of $10 \%$ DMSO instead of inhibitor. The experiment was performed in triplicates and the \% inhibition was calculated.

\section{Maltase glucoamylase inhibition study}

Assay for glucoamylase inhibition was carried out by slight modification of a previously published method [12]. Shortly, solutions of glucoamylase (from maltase) enzyme and its substrate p-nitrophenyl a-D-glucopyranoside ( $\mathrm{pNPG}$ ) were prepared in phosphate buffer (70
$\mathrm{mM}, \mathrm{pH}$ 6.8). Buffer was used for the preparation of inhibitor solutions. The inhibition assays were conducted by adding inhibitor solution (10 $\mu \mathrm{L})$ to $70 \mu \mathrm{L}$ buffer and $10 \mu \mathrm{L}$ of enzyme solution $(2.5 \mathrm{unit} / \mathrm{mL})$ in 70 $\mathrm{mM}$ phosphate buffer ( $\mathrm{pH}$ 6.8) followed by pre-incubation at $37{ }^{\circ} \mathrm{C}$ for $5 \mathrm{~min}$. After pre-incubation, $10 \mu \mathrm{L}$ of $10 \mathrm{mM}$ substrate (pNPG) prepared in phosphate buffer was added to the mixture to initiate enzymatic reaction. The reaction mixture was incubated at $37^{\circ} \mathrm{C}$ for $30 \mathrm{~min}$. Acarbose was used as a positive control. The glucoamylase activity was determined by measuring the p-nitrophenol released from pNPG at $405 \mathrm{~nm}$ using an Eliza micro plate reader. Each experiment was performed in triplicates. The $\%$ inhibition was calculated.

Statistical analysis: The total percentage inhibitions were calculated by method of [12]:

$$
\% \text { Inhibition }=\left[100-\left(\frac{\text { absorbancetestwell }}{\text { absorbancecontrol }}\right] \times 100\right.
$$

$\mathrm{IC}_{50}$ (i.e., the concentration of sample inhibiting 50\%) values of potent inhibitors were determined by testing the serial dilutions of inhibitors and were calculated by using the program PRISM 5.0 (GraphPad, San Diego, California, USA).

\section{GC/MS analysis}

GC-MS analysis of methanol and chloroform extracts of B.Micrantha barks was performed using TurboMass GC System, fitted with an Elite- 5 capillary column $(30 \mathrm{~m}, 0.25 \mathrm{~mm}$ inner diameter, 0.25 $\mu \mathrm{m}$ film thickness; maximum temperature $350{ }^{\circ} \mathrm{C}$, and coupled to a Perkin Elmer Clarus 600C MS. Helium was used as gas carrier at a constant flow rate of $1.0 \mathrm{~mL} / \mathrm{min}$. The injection, transfer line and ion source temperatures were $280^{\circ} \mathrm{C}$. The ionizing energy was $70 \mathrm{eV}$. The oven temperature was programmed from $70{ }^{\circ} \mathrm{C}$ (hold for $2 \mathrm{~min}$ ) to $280^{\circ} \mathrm{C}$ (hold for $10 \mathrm{~min}$ ) at a rate of $5^{\circ} \mathrm{C} / \mathrm{min}$. The crude extract was solubilised with chloroform and filtered with syringe filter (Corning, $0.45 \mu \mathrm{m}$ ). Volumes of $1 \mu \mathrm{L}$ of the crude extracts were injected with a split ratio 1:20. The data were obtained by collecting the mass spectra within the scan range $50-550 \mathrm{~m} / \mathrm{z}$. The identification of chemical compounds in the extracts was based on GC retention time; the mass spectra matched those of standards available at NIST library.

\section{Results}

Tables 1-4, Figures 1, 2 and 3.

\section{Discussion}

It is worthy to note that from the result of table 1 , the $\mathrm{IC}_{50}$ of methanolic extract $(1.06+0.1 \mu \mathrm{g} / \mathrm{mL})$ showed high inhibitory potential against $\alpha$-glucosidase than that of chloroform extract $\mathrm{IC}_{50}(2.84+0.1 \mu \mathrm{g} /$ $\mathrm{mL})$. However, the two results were better than the acarbose standard $(234.6 \pm 2.01 \mu \mathrm{M})$ against $\alpha$-glucosidase. The $\mathrm{IC}_{50}$ both for the extracts of B.micrantha against $\alpha$-glucosidase were better than the ethanolic extracts of Andrographis paniculata and andrographolide as reported by Rammohan [15] when compared. The extract of $A$. Paniculata showed $\alpha$-glucosidase inhibitory effect in a concentration-dependent manner $\left(\mathrm{IC}_{50}\right.$ of $17.2 \pm 0.15 \mathrm{mg} / \mathrm{mL}$ ) and andrographolide demonstrated a similar $\left(\mathrm{IC}_{50}\right.$ of $\left.11.0 \pm 0.28 \mathrm{mg} / \mathrm{mL}\right)$ against $\alpha$-glucosidase. Furthermore, the $\alpha$-glucosidase of the B.micrantha extracts were better than the methanolic extracts of Artocarpus altilis $\left(\mathrm{IC}_{50} 129.85+10.29 \mu \mathrm{g} / \mathrm{mL}\right.$ ), A.heterophyllus ( $\left.\mathrm{IC}_{50} 76.90+9.55 \mu \mathrm{g} / \mathrm{mL}\right)$, Cinnamomus zeylanicum $\left(\mathrm{IC}_{50} 140.01+0.08 \mu \mathrm{g} / \mathrm{mL}\right.$ ) and piper betel ( $\mathrm{IC}_{50} 96.56+12.93 \mu \mathrm{g} / \mathrm{mL}$ ) at concentrations ranged from 20 to $100 \mu \mathrm{g} / \mathrm{mL}$ as reported by Sindhu [16]. In addition, the methanolic extract of B.micrantha $\left(\mathrm{IC}_{50} 1.06+0.1 \mu \mathrm{g} /\right.$ 
Table 1. Inhibition potency of crude extracts against $\alpha$-glucosidase, maltase glucoamylase and $\beta$-glucosidase

\begin{tabular}{|c|c|c|c|}
\hline Extracts & $\begin{array}{c}\alpha \text {-glucosidase } \\
\mathrm{IC}_{50} \pm \operatorname{SEM}(\mu \mathrm{g} / \mathrm{mL})\end{array}$ & $\begin{array}{c}\beta \text {-glucosidase } \\
\% \text { inhibition } \pm S E M\end{array}$ & $\begin{array}{l}\text { Maltase glucoamylase } \\
\mathrm{IC}_{50} \pm \operatorname{SEM}(\mu \mathrm{g} / \mathrm{mL})\end{array}$ \\
\hline $\mathrm{CHCl}_{3}$ extract & $2.84 \pm 0.08$ & $24.53 \pm 3.64$ & $7.35 \pm 1.02$ \\
\hline $\mathrm{MeOH}$ extract & $1.06 \pm 0.11$ & $24.16 \pm 1.54$ & $1.12 \pm 0.10$ \\
\hline Acarbose $^{\mathrm{a}}$ & $234.6 \pm 2.01(\mu \mathrm{M})$ & Not tested & $234.6 \pm 2.01(\mu \mathrm{M})$ \\
\hline Castonospermine $^{\mathrm{b}}$ & Not tested & $59.98 \%[14]$ & Not tested \\
\hline
\end{tabular}

${ }^{\text {a }} \alpha$-glucosidase standard

${ }^{\mathrm{b}} \beta$-glucosidase standard

\pm SEM: standard Error mean

Table 2. Identified compounds in the chromatogram of methanolic extract

\begin{tabular}{|c|c|c|c|}
\hline Compound name & Molecular formula & CAS & $\begin{array}{l}\text { Molecular Retention time } \\
\text { weight (g.mol }{ }^{-1} \text { ) (minutes) }\end{array}$ \\
\hline Valeric acid & $\mathrm{C}_{21} \mathrm{H}_{42} \mathrm{O}_{2}$ & $125164-54-7$ & 32611.822 \\
\hline L-Ascorbic acid,6-octadecanoate & $\mathrm{C}_{24} \mathrm{H}_{42} \mathrm{O}_{7}$ & $10605-09-1$ & 44231.442 \\
\hline Oxalic acid ,butyl-6-ethyloct-3-yl-ester & $\mathrm{C}_{16} \mathrm{H}_{30} \mathrm{O}_{4}$ & $900309-34-3$ & 28613.608 \\
\hline Menthol & $\mathrm{C}_{10} \mathrm{H}_{20} \mathrm{O}$ & $1490-04-6$ & 15642.89 \\
\hline Phytol & $\mathrm{C}_{20} \mathrm{H}_{40} \mathrm{O}$ & $150-86-7$ & 29628.639 \\
\hline Stearic acid,2-phenyl-M-dioxan-5-yl ester trans & $\mathrm{C}_{28} \mathrm{H}_{46} \mathrm{O}_{4}$ & $10564-35-9$ & 44610.842 \\
\hline Phenol3.5-Bis(1,1-dimethyl ethyl) & $\mathrm{C}_{14} \mathrm{H}_{22} \mathrm{O}$ & $1138-52-9$ & 20620.241 \\
\hline Myristic acid vinyl ester & $\mathrm{C}_{16} \mathrm{H}_{30} \mathrm{O}_{2}$ & $5809-91-6$ & 25449.638 \\
\hline Vitamin A Aldehyde & $\mathrm{C}_{20} \mathrm{H}_{28} \mathrm{O}$ & $116-31-4$ & 28416.784 \\
\hline 3-Methyl-2-(2-oxopropyl)Furan & $\mathrm{C}_{8} \mathrm{H}_{10} \mathrm{O}_{2}$ & $87773-62-4$ & 13820.841 \\
\hline 1H-Imidazole,1-(1ioxooctadecyl) & $\mathrm{C}_{21} \mathrm{H}_{88} \mathrm{ON}_{2}$ & $17450-32-7$ & 33420.526 \\
\hline D-mannitol, 1-decylsulfonyl & $\mathrm{C}_{16} \mathrm{H}_{34} \mathrm{O}_{7} \mathrm{~S}$ & 900154-76-1 & 37050.274 \\
\hline
\end{tabular}

Table 3. Identified compounds in the chromatogram of chloroform extract

\begin{tabular}{|l|c|c|c|}
\hline Compound name & Molecular formula & CAS & $\begin{array}{l}\text { Molecular Retention time } \\
\text { weight (g.mol }\end{array}$ \\
\hline 3-methyl-2-(2-oxopropyl) Furan & $\mathrm{C}_{8} \mathrm{H}_{10} \mathrm{O}_{2}$ & $87773-62-4$ \\
\hline Z,Z-6,28-Heptatriactontadiene-2-one & $\mathrm{C}_{37} \mathrm{H}_{70} \mathrm{O}$ & $133530-21-9$ \\
\hline 1,10-Hexadecanediol & $\mathrm{C}_{16} \mathrm{H}_{34} \mathrm{O}_{2}$ & $39516-54-6$ & 13811.707 \\
\hline (Z)-14-tricosenyl formate & $\mathrm{C}_{24} \mathrm{H}_{46} \mathrm{O}_{2}$ & $77899-10-6$ & 53851.313 \\
\hline 3-T-Butyl-oct-6-yn-1-ol & $\mathrm{C}_{12} \mathrm{H}_{24} \mathrm{O}$ & $900185-34-1$ \\
\hline Cis-1-chloro-9-octadecene & $\mathrm{C}_{18} \mathrm{H}_{35} \mathrm{Cl}$ & $16507-61-2$ \\
\hline 4-N-Hexylthiane,s,s-dioxide & $\mathrm{C}_{11} \mathrm{H}_{22} \mathrm{O}_{2} \mathrm{~S}$ & 36621.176 \\
\hline
\end{tabular}

OSIRIS drug properties and toxicity profile

Table 4. Drug properties of some of identified compounds in the crude extracts determined by OSIRIS property explorer

\begin{tabular}{|c|c|c|c|c|c|c|c|c|c|c|}
\hline Compound & $\begin{array}{c}\text { Drug } \\
\text { likeness }\end{array}$ & Mutagenic & Tumorigenic & $\operatorname{cLogS}$ & CLogP & $\begin{array}{c}\text { Polar } \\
\text { surface } \\
\operatorname{area}\left(\AA^{2}\right)\end{array}$ & $\%$ Absoption & $\begin{array}{l}\text { H-bond } \\
\text { Acceptor }\end{array}$ & $\begin{array}{l}\text { H-bond } \\
\text { Donor }\end{array}$ & Irritability \\
\hline Valeric acid & -7.0646 & None & None & -1.269 & 1.0641 & 37.3 & 96.13 & 2 & 1 & None \\
\hline Menthol & -25.216 & High & None & -2.501 & 2.4112 & 20.23 & 102.02 & 2 & 1 & None \\
\hline Phytol & -3.7661 & None & High & -4.633 & 7.4212 & 20.23 & 102.02 & 1 & 1 & High \\
\hline $\begin{array}{l}\text { 1H-imidazole (identified compound] having } \\
\text { imidazole ring) }\end{array}$ & 0.44659 & None & None & -0.431 & -0.1802 & 28.68 & 99.11 & 2 & 1 & None \\
\hline Ascorbic acid & \multirow{2}{*}{0.023806} & \multirow{2}{*}{ None } & \multirow{2}{*}{ None } & \multirow{2}{*}{-0.349} & \multirow{2}{*}{-2.8448} & \multirow{2}{*}{90.15} & \multirow{2}{*}{77.9} & \multirow{2}{*}{6} & \multirow{2}{*}{4} & \multirow{2}{*}{ None } \\
\hline (molecular aspect) & & & & & & & & & & \\
\hline
\end{tabular}

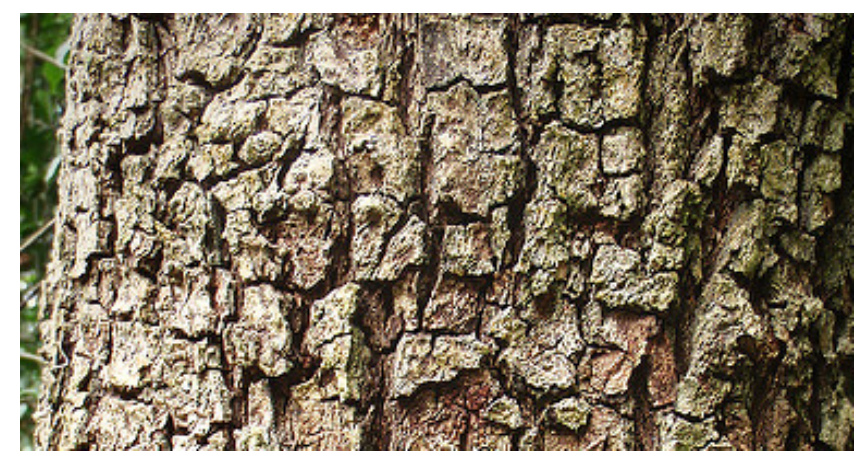

Figure 1. Bark of Bridelia micranth 


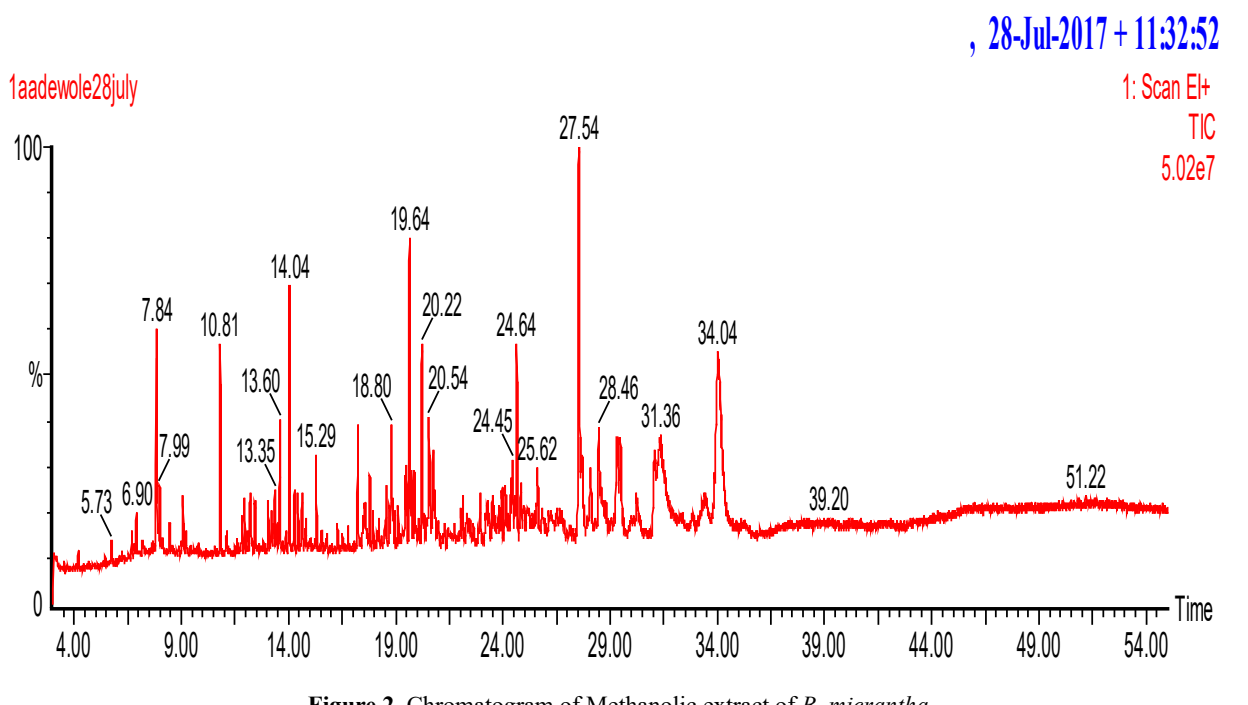

Figure 2. Chromatogram of Methanolic extract of B. micrantha

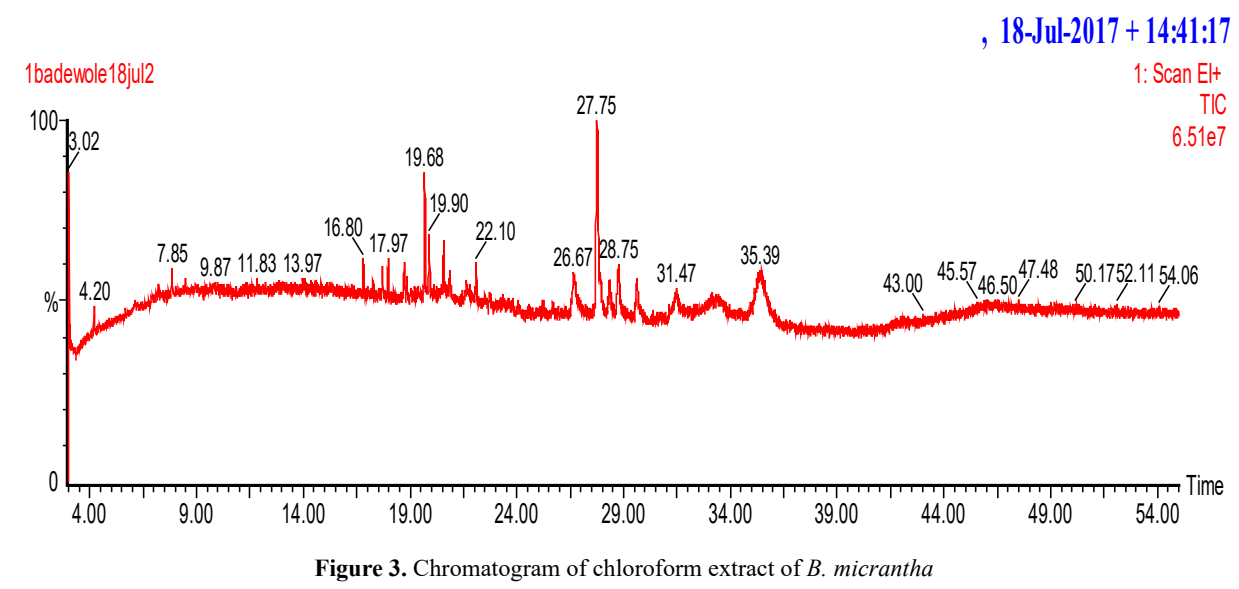

$\mathrm{mL}$ ) showed good potent and selective inhibitor than A.calamus $\left(\mathrm{IC}_{50}\right.$ $1.26 \mathrm{mg} / \mathrm{mL})$ and N.sativa $\left(\mathrm{IC}_{50} 1.53 \mathrm{mg} / \mathrm{mL}\right)$ as reported by Balaji [17] against $\alpha$-glucosidase. The $\mathrm{IC}_{50}(1.12+0.10 \mu \mathrm{g} / \mathrm{mL})$ of methanolic extract of B.micrantha was better than the chloroform extract of $\mathrm{IC}_{50}(7.35+1.02$ $\mu \mathrm{g} / \mathrm{mL}$ ) when tested against maltase glucoamylase and the results were better than the standard acarbose $\left(\mathrm{IC}_{50} 234.6 \pm 2.01 \mu \mathrm{M}\right)$. However, the $\mathrm{IC}_{50}$ both for the extracts of B.micrantha against maltase glucoamylase showed good inhibitory potentials than the methanolic extracts of Artocarpus altilis ( $\left.\mathrm{IC}_{50} 118.88+11.14 \mu \mathrm{g} / \mathrm{mL}\right)$, A.heterophyllus $\left(\mathrm{IC}_{50}\right.$ $70.58+9.66 \mu \mathrm{g} / \mathrm{mL}$ ), Cinnamomus zeylanicum $\left(\mathrm{IC}_{50} 130.55+10.5 \mu \mathrm{g} /\right.$ $\mathrm{mL}$ ) and piper betel $\left(\mathrm{IC}_{50} 84.63+13.09 \mu \mathrm{g} / \mathrm{mL}\right)$ at concentrations ranged from 20 to $100 \mu \mathrm{g} / \mathrm{mL}$ as reported by Sindhu [16]. The $\beta$-glucosidase screening of the B.micrantha extracts showed that they do not potent and selective inhibition, the methanolic extract had $24.16+1.54 \%$ and chloroform extract had $24.53+3.64 \%$ inhibitory potential against $\beta$-glucosidase and these values were less than the Castonospermine standard (59.98\%) as reported by Verma [14].

Moreover, the good potent and inhibitory potentials of the extracts of B.micrantha against $\alpha$-glucosidase and maltase glucoamylase are good indication that the plant possesses therapeutic properties. The identification of bioactive compounds as revealed by gas chromatography Mass spectrophotometer has shown that the efficacy of the plant being used for the treatment of diabetes mellitus may not be unconnected to the presence of the these bioactive compounds both in the chloroform and methanolic extracts as many heterocyclic compounds have been found to possess various pharmacological activities against different ailments.

In addition, in the characterization, the results of GC-MS profile can be employed as a tool for the identification of novel compounds [18] as revealed in tables 2 to 3 . It is interesting to note that some of the identified compounds in the crude extracts were screened computationally using online OSIRIS property explorer server [19] and were found to possess various drug properties as shown in Table 4.It has been reported that molecular properties which include bioavailability, hydrophobicity and membrane permeability are linked with some molecular descriptors as CLog P (partition coefficient), cLogS (solubility) number of $\mathrm{H}$-bond acceptors and $\mathrm{H}$-bond donors and molecular weight. It is documented that Lipinski's rule of five [20] is widely used to predict molecular drug-likeness. According to the rule, a drug like molecule has $\log \mathrm{P} \leq 5$, molecular weight $<500 \mathrm{~g} / \mathrm{mol}$, hydrogen bond acceptors $\leq 10$, hydrogen bond donors $\leq 5$ and molar refractivity between 40-130. Molecules violating more than one of these rules are not expected to be viable drug candidates. The solubility parameter, log $\mathrm{S}$, is another important parameter for determining drug likeness. The absorption of a compound is considerably influenced by its solubility. Generally, high $\log \mathrm{S}$ values correspond to good absorption. Molecular polar surface area (PSA) is a very useful parameter for the prediction of drug transport properties (PSA must be $\leq 140 \AA^{2}$ ). It is used to 
estimate the percentage of absorption using the expression \%ABS=1090.345 PSA [21]. The online OSIRIS property explorer server has revealed the relevance and various drug properties of some of the identified compounds in the crude extracts using GC-MS and this could serve as a tool for the pharmaceutical chemists to further research on the plant as a potential anti-diabetic agent.

\section{Statement of significance}

This study discovered the potent anti-diabetic inhibitory potentials of the methanolic and chloroform crude extracts of $B$. micrantha against $\alpha$-glucosidase and maltase glucoamylase which can be highly beneficial for the treatment of diabetes mellitus type 2. Also, the online OSIRIS server explorer has revealed the drug properties of some of the identified compounds which will be beneficial to the scientists for further investigation. This study could be explored by researchers and a new anti-diabetic agent may be arrived at.

\section{Acknowledgement}

Dr. Adewole E. sincerely appreciates 'The world academy of science' (TWAS) for the Postdoctoral fellowship opportunity granted at the centre for Advanced Drug Research, COMSATS Institute of Information Technology, Abbottabad, Pakistan in 2017.

\section{References}

1. Palanisamy UD, Ling LT, Manaharan T, Appleton D (2011) Rapid isolation of geraniin from Nephelium lappaceum rind waste and its anti-hyperglycemic activity. Food Chem Toxicol 127: 21-27.

2. Patel DK, Kumar R, Laloo D, Hemalatha S (2012) Natural medicines from plant source used for therapy of diabetes mellitus: an overview of its pharmacological aspects. Asian Pac J Trop Biomed 2: 239-250.

3. Patel DK, Prasad SK, Kumar R, Hemalatha S (2012) An overview on antidiabetic medicinal plants having insulin mimetics property. Asian Pac J Trop Biomed 2: 320330. [Crossref]

4. Sunila C, Agastian P, Kumarappan C, Ignacimuthu S (2012) In vitro antioxidant, antidiabetic and antilipidemic activities of Symplocos cochinchinensis (Lour.) $\mathrm{S}$. Moore bark. Food Chem Toxicol 50: 1547-1553.

5. Ghani A (2003) Medicinal Plants of Bangladesh. second editon 55: 402-500

6. Omeh YN, Onoja SO, Ezeja MI, Okwor PO (2014) Subacute antidiabetic and in vivo antioxidant effects of methanolic extract of Bridelia micrantha (Hochst Baill) leaf on alloxan-induced hyperglycaemic rats. J Complement Integr Med 11: 99-105.
7. Nwaehujor CO, Igile GO, Ode JO, Udegbunam RI (2014) Anti-Inflammatory activities of methanol leaf extract of Bridelia micrantha (Hochst) Baill. (Euphorbiaceae) in wistar rats. J Appl Pharm Sci 5: 68-73.

8. Adika OA, Madubunyi II, Asuzu IU (2012) Anti-diabetic and antioxidant effects of the methanol extract of Bridelia micrantha(Hochst) Baill. (Euphorbiaceae) leaves on alloxan-induced diabetic albino mice. Comp Clin Pathol 21: 945-951.

9. Nwaehujor CO, Udeh NE (2011) Screening of ethyl acetate extract of Bridelia micrantha for hepatoprotective and anti-oxidant activities on wistar rats. Asian Pac J Trop Med 4: 796-800.

10. Steenkamp V (2003) Traditional herbal remedies used by South African women for gynaecological complaints. J Ethnopharmacol 86: 97-108. [Crossref]

11. Mburu C, Kareru1 PG, Kipyegon C, Madivoli ES, Maina EG, et al. (2016) Phytochemical Screening of Crude Extracts of Bridelia micrantha. European Journal of Medicinal Plants 16: 1-7.

12. Ma HY, Gao HY, Sun L, Huang J, Xu XM, et al. (2011) Constituents with alphaglucosidase and advanced glycation end-product formation inhibitory activities from Salvia miltiorrhiza Bge. J Nat Med 65: 37-42.

13. Pérez M, Muñoz FJ, Muñoz E, Fernández M, Sinisterra JV, et al. (2008) Synthesis of novel glycoconjugates and evaluation as inhibitors against $\beta$-glucosidase from almond. J Mol Catal B Enzym 52: 153-157.

14. Verma N, Behera BC, Sharma BO (2012) Glucosidase inhibitory and radical scavenging properties of lichen metabolites salazinic acid, sekikaic acid and usnic acid. Hacett $J$ Biol Chem 40: 7-21.

15. Rammohan S, Zaini Asmawi M, Amirin S (2008) In vitro a-glucosidase and a-amylase enzyme inhibitory effects of Andrographis paniculata extract and andrographolide. Acta Biochimica Polonica 55: 391-398

16. Sindhu SN, Vaibhavi K, Anshu M (2013) In vitro studies on alpha amylase and alpha glucosidase inhibitory activities of selected plant extracts. European Journal of Experimental Biology 3: 128-132.

17. Balaji RM, Chitra J, Meenakshi K, Sundaram (2015) Studies on Antidiabetic Activity of Indian Medicinal Plants Using -Amylase and -Glucosidase Inhibitory Activity - A Pathway to Antidiabetic Drugs. World Journal of Medical Sciences 12: 207-212.

18. Shettar AK, Sateesh MK, Kaliwal BB, Vedamurthy AB (2017) In vitro antidiabetic activities and GC-MS phytochemical analysis of Ximenia americana extracts. South African Journal of Botany 111: 202-211.

19. Sander T (2001) OSIRIS property explorer. Allschwil: Actelion Pharmaceuticals Ltd. Available at http://www.organicchemistry. org/prog/peo/index.html.

20. Lipinski CA, Lombardo F, Dominy BW, Feeney PJ (2001) Experimental and computational approaches to estimate solubility and permeability in drug discovery and development settings. Adv Drug Deliv Rev 46: 3-26. [Crossref]

21. Wang RX, Fu Y, Lai LH (1997). 'A new atom-additive method for calculating partition co-efficients. J Chem Inf Comput Sci 37: 615-621.

Copyright: (C2018 Ezekiel A. This is an open-access article distributed under the terms of the Creative Commons Attribution License, which permits unrestricted use, distribution, and reproduction in any medium, provided the original author and source are credited. 